\title{
Indirectness in police interviews
}

\author{
L. V. Pavlichenko', O. O. Brechak ${ }^{2}$
}

\author{
${ }^{1}$ Taras Shevchenko National University of Kyiv \\ ${ }^{2}$ National Academy of Fine Arts and Architecture \\ Corresponding author. E-mail: la.pavlichenko@gmail.com
}

Paper received 03.02.21; Accepted for publication 16.02.21.

\section{https://doi.org/10.31174/SEND-Ph2021-248IX73-17}

\begin{abstract}
The article studies the pragmatic characteristics of the discourse of police interrogation that come from the main goals of the interrogation discourse. The research focuses on the indirect speech acts in their correlations with conversational implicatures. Indirectness is typical for manipulative strategies of an investigator if confronted with sabotage or false data from interrogees. Indirect "face-threatening" acts are applied combined with lexical and grammatical means of mitigation to disguise impact and pressure on the interrogated person.
\end{abstract}

Keywords: discourse of interrogation, indirect speech acts, investigator, interrogee, conversational implicatures.

Introduction. Modern linguistics solves the problem of improving the effectiveness of communication in various spheres of human life. Particular attention is paid to the study of interpersonal communication and the peculiarities of its functioning in the institutional sphere. A comprehensive study of the discourse of police interrogation at the stage of pre-trial investigation remains relevant today. Pragmatic characteristics of the this discourse are formed by its main purpose, namely, to obtain information which is lacking on the case and to disclose the crime. The paper explores the communicative intentions of the investigator with a particular focus on indirect speech acts and their markers in the discourse of interrogation.

The purpose of the study is to identify the types of indirect speech acts of the investigator, and their manifesting indices. The object of the research is the speech acts represented by the investigator. The subject of the article is the communicative-pragmatic and linguistic foci of the realization of an investigator's intention.

The material of the study were transcripts of interrogations at the stage of pre-trial police investigation in the United States, which were obtained by the method of continuous sampling.

Theoretical background. The research bases on the theory of speech acts presented by Ostin and Searle. [3, 9, 10] By a speech act, after Arutyunova [1], we mean a separate act of speech, which is a two-way process of generating a text, covering speech and simultaneous auditory perception and understanding of what is heard.

The classification of speech acts takes into account their illocutionary purpose, the psychological state of the speaker [1], the type of relations between the propositional content of speech acts and the state of affairs in the world, the relation to the interests of the speaker and the addressee.

In our study, we used classification of speech acts by $G$. Pocheptsov [4] who refers to illocutionary types of utterances as pragmatic types of sentences. In this classification, the nature of the pragmatic component is essential for identification of the pragmatic types, establishing their taxonomy considering both their illocutionary goal, and the way to achieve it, and includes statements, premixes, menasives, directives, performatives, quesitives. Special attention was paid in the article to cases when the illocutionary force of a speech act is based on implicature.

Methods. The study applies methodology which includes the use of general scientific methods of observation, systematization and generalization combined with the number of linguistic methods: pragmatic and semantic analyses, methods of the analyses of speech acts and conversational implicatures identification.

Discussions and results. The communicative intention of an interrogating police officer at the initial stage of investigation (pre-trial investigation) consists of accumulating maximum true data relevant to the crime. Accordingly, the pragmatic goal of an investigator is to apply impact on the interrogee and force him to supply data or confess the crime.

The material allowed to identify the main types of indirect speech acts through which the investigator realizes his status role and the main institutional strategies in the interrogation discourse.

Representatives whose "quesitive" illocutionary force is specified by the perlocutionary reaction of the interrogated: mentioning the information that is supposed to be presented by the interrogee, the interrogator implicitly forces him to react to the statement of fact as to a question, confirming or refuting the given information:

1) So, you went in the house. [BD]

2) Detective Baldwin: And he is working today, you said. [BD]

Dassey: I don't know anything.

3) You just got done tellin' us that she was out taking picture. $[B D]$ The investigator by reminding the recent piece of information makes the interrogee agree or deny it, continue developing the topic, comment and give further answers.

4)-If I was to ask you were you on it this morning, that would be a no. Unreal conditional clause of the police officer implies the question ("Were you on it this morning?").

- I was not on it this morning. [PM] The negative answer from the interrogee proves the primary illocutionary force of the quesitive speech act.

Pursuing the main goal of obtaining a confession, a police officer employs a number of manipulative techniques characteristic primarily for the stages of interrogation when a suspect or an accused person sabotages or refuses to cooperate. For an investigator it is typical to use speech acts with the directive illocution in the form of representatives masking the directiveness and provoking an interrogee to reveal more details. Lexical and grammatical mitigation is a characteristic feature accompanying indirectness in inter- 
rogation to avoid "face-threatening acts" [8]. By Selivanova O., mitigation is a communicative strategy for softening the speech for the interlocuter to decrease the risks of arguments, refusal, avoid conflicts and increase the effectiveness of communicative actions. [5, p. 420]

Representatives in the functions of directives:

Directives are represented in the form of representatives with the primary directive illocutionary force "Don't disappoint us" (1), "Tell us what you know", "Tell us the truth" (2), "Help us" (5), "Tell us what happened" $(3,6)$, "Don't lie. $(4,7)$ Tell what you have seen" $(7)$. The following examples comprise such mitigation means, as to be going to construction (1), present continuous (1), complex object (7), emphatic construction (4), modal verbs $(2,5,6)$, verb of volition and similarity (want, look like)(3):

1) Brendan, you are not going to disappoint any of us. [BD] You are not telling me something. [BD]

2) We have to know the truth. [BD]

3) You look like you want to tell me something. [BD]

4) The only way to make your mistakes right is by telling the truth. [BD]

5) But now you can do the right thing, you can help us find her. [BD]

6) Dassey: I don't know where she is.

Detective Baldwin: Yeah, but you can give us an idea what happened to her. [BD]

7) We don't want you to to tell us anything that you didn't see. [BD]

But ifyou've seen something, I want you to tell us. [BD]

Mitigation of the indirect speech act is achieved due to application of the verb forms of present and past subjunctive with the verb of believing and supposition (think), modal words (may be), modal verbs (can, need) an adverb just.

8) I would think that may be you would remember that, you would have a reason to remember that. [PM]

9) If you can work with me a little bit. [PM]

10) We can not have back what happened, but we can make it right. And how do we make it right? Just by being honest. [PM]

11) We need to know everything about what happened so we can figure that out. [BD]

12) I know you said that, but there should be a little more to it. $[P M]$. In this utterance, the investigator disregards the maxim of quantity of information triggering the conversational implicature: reveal extra details of the crime. Accordingly, the implicature becomes the basis for interpreting the representative as an indirect directive.

Thus, in order to compensate face threat to the person being interrogated, the indirect directive is additionally mitigated by a complex of lexical-grammatical means, reducing the imposition and pressure on the interlocutor.

Quesitives in the function of invective and directives are the complex speech acts, by Slavova L., with double functioning in the framework of one type of discourse [6, p. 323] representing a negative assessment of the interrogee and his actions and threatening his "positive face" [8]:

1) Dassey: I don't know anything.

Det. Baldwin: Why are you lying to me about this? [BD]

The following examples (2-5) demonstrate idiomatic indirect directives with primary illocutionary force tell me, help us and secondary illocutionary force of quesitives as negative-interrogative questions aimed at reducing direct imposition, emphasize personal involvement and compassion (personal pronouns $m e$ )

2) Why don't you tell me what happened to her? [BD]

3) I think you know. Why don't you tell me? [BD]

4) Why don't you tell me what you know? [BD]

5) She is not here any more, we want to get her back to her parents. Why don't you help us do that? [BD]

Quesitives in the function of idiomatic indirect directives are presented in the interrogation discourse by general questions with modal verbs (can):

1) Can you tell me when was the last time? [PM]

2) Can you call something to mind, Philip? [PM]

3) Can you picture it? [PM]

4) Can you recall anything like that? [PM]

The emphatic construction in (6) amplifies the illocutionary force of indirect speech act (directive) and combines with a simple gerund:

5) The only way to make your mistakes right is by telling the truth. [BD]

The directive (7) presented in the form of disjunctive question is mitigated by a personal pronoun and a verb of personal opinions, supposition (I think), indefinite pronoun something that is a means of indirect hint on the fact known to the police. The directive illocution ("Tell us what happened to her) is based here on conversational implicature (We know something happened) triggered by flouting the maxim of quantity of information, marked by lexical redundancy - hedge (I think) and mitigation means (something, probably, tag question).

6) I think you know something probably happened to her, didn't you? [BD]

The further investigation revealed some rare examples of:

a) quesitives used with the illocutionary force of menacives with present conditional structures:

What happens if we find his prints inside the car? You think that is possible? [PM];

b) representatives in the functions of menacives:

Mitigated indirect menacives are manifested in the form of representatives and implemented by Complex object and verbs with the semantics of volition combined with lexical means of negative semantics (caught up in, get things wrong), negative forms of Present simple with Complex Object and simple infinitive, personal pronoun $I$ implying personal involvement, compassion and sympathising being used as mitigation means.

1) I don't want you to get caught up in something that you don't deserve to be caught up in. [BD]

2) I am here to tell you, Idon't want to get things wrong. [BD]

c) quesitives in the function of invectives:

It has only been a week or two. You don't have a memory of being there in the last week or so? [PM]

The adverb only due to its inference pattern triggers the conventional implicature of the complex sentence with the concessive clause ("Though it has only been a week or two, you don't remember being there") that doubts the refusal of the interrogee to comment on the past events.

d) representatives in the functions of invectives:

1)You know mistakes happen. Bad things happen sometimes. You understand that? Sometimes it does, people do not mean to make mistakes, but they do. [BD] Indirect men- 
acives are presented in the form of representatives involving generalization as a means of minimizing the fault and facilitating the confession mitigated by personal pronouns, lexical means of general semantics (you, people) and lexical and semantic means with the semes of unintended action (do not mean).

The results of analysis of the interrogator's indirect speech acts are summerised in the following table:

Table 1. Indirect speech acts of an interrogator and their illocutionary forces

\begin{tabular}{|l|l|l|l|l|l|}
\hline Form/illocution & quesititive & menacive & directive & invective & $\begin{array}{l}\text { directive, } \\
\text { invective }\end{array}$ \\
\hline representatives & + & + & + & + & \\
\hline quesitives & & + & + & + & + \\
\hline directives & & + & & & \\
\hline
\end{tabular}

Conclusion. On the basis of the work carried out, we have come to the following conclusion:

1. It is typical for the language of an investigator to use indirect speech acts in order to avoid acts of direct imposition which are presented in the form of representatives, quesitives and directives.
2. The investigator resorted to manipulative techniques in case of sabotage or pseudo-cooperation on the part of an interrogated person using speech acts of directive, menacive, invective and a complex directive and invective illocutionary force with structural indicators of representative, questitive and directive speech acts.

3. The illocution of an indirect act can be based on a conversational implicature triggered by the investigator's disregard of the maxims of quantity and manner (transparency) of information due to the excessive use of hedges and mitigation, or, on the contrary, excessive laconicism and reticence.

4. Finally, it can be observed that indirect "face-threatening" acts are applied combined with lexical and grammatical means of mitigation for reducing the categorical and straightforward speech of the investigator in the form of personal and indefinite prounouns, modal verbs, negative-interrogative constructions, Complex object, simple infinitives, forms of gerund, as well as continuous forms as grammatical means of expressing respect to the interlocutor.

\section{ЛИТЕРАТУРА}

1. Арутюнова Н. Д. Речевой акт / Арутюнова Н. Д. // Лингвистический энциклопедический словарь / Гл. ред. В.Н. Ярцева. М.: Сов. энциклопедия, 1990. С. 412-413.

2. Бацевич Ф. С. Основи комунікативної лінгвістики / Бацевич Ф. С. , К.: Академія, 2004. 344 с.

3. Остин Дж. Теория речевых актов [Текст] / Джон Остин // Новое в зарубежной лингвистике [под ред. Б.Ю. Городецкого], М.: Прогресс, 1986. С. 167-196.

4. Почепцов Г.Г. Предложение / И.П. Иванова, В.В. Бурлакова, Г.Г. Почепцов. Теоретическая грамматика современного английского языка. М.: Высшая школа, 1981. С. 164281.

5. Селіванова О. О. Лінгвістична енциклопедія. Полтава : Довкілля-К, 2010. 844 с.

6. Славова Л.Л. Домінантні мовленнєві акти у складі дискурсу американського і українського політика. [Electronic Resource]. Mode of access: http://studia-linguistica.knu.ua/dominantni-movlennievi-akti-u-skladi-diskursuamerikanskogo-ta-ukrainskogo-politika/

7. Сусов И.П. Лингвістическая прагматика. Вінниця: Нова

книга, 2009. $272 \mathrm{c.}$

8. Brown, P., Levinson, S. C. Politeness: Some Universals in Language Usage. Cambridge: Cambridge University Press, 1987. $345 \mathrm{p}$.

9. Kasper, G. Linguistic politeness: Current research issues. Journal of Pragmatics, 14, 1990. P. 193-218.

10. Searle, J.R. A taxonomy of illocutionary acts. In Language, mind and knowledge. Gunderson, K. (ed.). Minneapolis, MN : University of Minnesota Press, 1975. P. 344-369.

11. Searle, J.R.. What is a speech act? In Language and language use. Pugh, A. K. 1980. P. 312-327.

12. Searle, J.R. \& Vanderveken, D. Foundations of illocutionary logic. Cambridge: Cambridge University Press, 1985. 231 p.

13. Transcript of interview of Brendan Dassey. [Electronic Resource]. Mode of access: http://www.stevenaverycase.org/wpcontent/uploads/2016/02/Brendan-Dassey-Interview-atSchool-Transcript-2006Feb27

14. Philip Markoff Police Interview. [Electronic Resource]. Mode of access: http://murderpedia.org/male.M/images/markoffphilip/philip-markoff-police-interview.pdf

\section{REFERENCES}

1. Arutyunova N.D. Speech act / Arutyunova ND // Linguistic encyclopedic dictionary / Ch. ed. V.N. Yartseva. M .: Sov. Encyclopedia, 1990. pp. 412-413.

2. Batsevich F.S. Fundamentals of communicative linguistics / Batsevich FS: Academy, 2004. 344 p.

3. Austin J. Theory of speech acts [Text] / John Austin // New in foreign linguistics [ed. B.Yu. Gorodetsky]. M.: Progress, 1986. S. 167-196.

4. Pocheptsov G.G. Proposal / I.P. Ivanova, B.B. Burlakova, G.G. Pocheptsov. Theoretical grammar of modern English. M .:
Higher school, 1981. S. 164-281.

5. Selivanova O.O. Linguistic encyclopedia. Poltava: Environment-K, 2010. 844 p.

6. Slavova L.L. Dominant speech acts in the discourse of American and Ukrainian politicians. [Electronic Resource]. Mode of access: http://studia-linguistica.knu.ua/dominantni-movlennievi-akti-u-skladi-diskursu-amerikanskogo-ta-ukrainskogopolitika/

7. Susov I.P. Linguistic pragmatics. Vinnytsia: New book, 2009. $272 \mathrm{p}$. 